\title{
Trainee Teacher Experience in Geoscience Education: Can We Do Better?
}

\author{
Núria Roca ${ }^{1}$ (D) $\cdot$ Maite Garcia-Valles ${ }^{2}$ (D) \\ Received: 24 December 2019 / Accepted: 11 November 2020/Published online: 16 November 2020 \\ (C) The European Association for Conservation of the Geological Heritage 2020
}

\begin{abstract}
Some organizations have warned that most secondary school curricula do not include a substantial geology component. Inadequate geological knowledge affects not only university students but also the majority of citizens who finish their secondary studies without having learned any basic geological concepts. The insufficient geological training of pre-university teachers who are later expected to teach some geology generates a certain degree of insecurity and fear about teaching geology. Therefore, it is imperative to improve training for trainee teachers to replace usual ways of thinking about geology teaching with new approaches that promote significant geological learning. This research has a dual objective: first, we analyze whether trainee teachers' theses include geoscience content; second, we explore how innovative ideas and practices can be translated for educational purposes and to promote geologically significant learning. Our findings reveal that environmental impacts, plate tectonics and the hydrosphere are concurrent topics in the geosciences. However, trainee teachers in Spain prefer to develop biology units because many of them have training in bioscience fields of knowledge. Traditional education based on the exposition of learning material by the teacher was identified as the main learning environment developed in the trainee teachers' theses. However, the number of innovations incorporated into trainee teachers' theses has increased. Through this process, trainee teachers have a critical role to play: encouraging their future secondary students to develop geology knowledge.
\end{abstract}

Keywords Secondary education $\cdot$ Teacher education $\cdot$ Geoscience $\cdot$ Geology $\cdot$ Active learning

\section{Introduction}

\section{Earth Science as an Underdeveloped Area of the Curriculum}

Science and technology are vital elements of the development and future growth of humans. The sciences are introduced early in secondary schools. In southern Europe (Calonge et al. 2012) and most Latin American countries (UNESCO 2019a), biology and geology are the two science disciplines that must share teaching time. However, currently, geology

Núria Roca

nroca@ub.edu

1 GI-GRIMS Group, Departament de Biologia Evolutiva, Ecologia i Ciències Ambientals, Facultat de Biologia, Universitat de Barcelona, Av. Diagonal 643, 08028 Barcelona, Spain

2 GI-GRIMS Group, Departament de Mineralogia, Petrologia i Geologia Aplicada, Facultat de Ciències de la Terra, Universitat de Barcelona, Carrer Martí i Franquès, s/n, 08028 Barcelona, Spain instruction is a limited, compulsory part of science and geography curricula and may be available through additional or optional courses in countries such as Australia (DawbornGundlach et al. 2017) and the USA (Lewis 2008). East Asian countries generally teach earth science through science classes, where it is taught mainly by earth science specialist teachers, and in some countries of Northern Europe, it is mainly only taught through geography courses (King 2013).

The teaching of the geosciences during the Spanish secondary compulsory education cycle (between the ages of 12 and 16) occurs only in the 1st and 3rd years. Biology and geology courses are optional in the last year of the second cycle of compulsory secondary education (ESO), and geological content comprises only between 15 and 33\% of their total course content (Pedrinaci 2014). At the baccalaureate level, an optional course in earth and environmental science is offered.

According to King et al. (2013), half of all 5- to 7-year-olds $(52 \%)$ in the 32 countries studied had received compulsory earth science education; four-fifths of 7- to 11-year-olds $(80 \%)$ were similarly educated, as were more than four-fifths (84\%) of 11- to 14-year-olds and nearly three-quarters (74\%) 
of 14- to 16-year-olds. However, only approximately onethird of 16- to 18 -year-olds (35\%) had received compulsory earth science education. In the USA, secondary earth and space science is most commonly taught at the 8 th or 9 th grade level, and only approximately $7 \%$ of high school students in the USA take earth and space science as opposed to $88 \%$ who take biology (Barstow and Geary 2002). In some countries such as the USA (Lewis 2008) and Spain (Pedrinaci 2012), geoscience subjects are frequently offered to students who are "unmotivated and unable to do "real" science, such as chemistry and physics'. Geoscience has also been an underrepresented subject in Australia. In the state of Victoria, geology as a year 12 subject ceased to exist after the early 1990s. Although it is still offered in other states, enrolment remains low (Dawborn-Gundlach et al. 2017). At the Argentine secondary education level, geological content is almost nonexistent within the Priority Learning Nucleus (NAP) of natural sciences for the common cycle of all high schools. Such content is also absent at much of the secondary education level except in orientations in 'natural sciences' and 'environment', which have created the new specific curricular subject of 'earth sciences' (Lacreu 2017). The 2019 UNESCO International Geoscience and Geoparks Programme for 35 non-Latin American countries finds that earth science coverage in curricula across the globe is variable and shows scope for major improvement in several areas and regions (UNESCO 2019b). In primary and secondary education in Latin American countries, earth sciences coverage in primary school curricula is limited, and in secondary school, it is not viewed as essential knowledge for the exercise of active citizenship (UNESCO 2019a). Therefore, recently, some international organizations have warned that most secondary school curricula do not include a substantial geology component (Pedrinaci 2014).

Inadequate geological knowledge affects the majority of citizens, who may complete their secondary studies without having learned any basic geological concepts. The resulting gap may have resulted in too few college students choosing to study geology. In Spain, the number of students enrolled in all university geology programs decreased from 5139 students in the 2000-2001 academic year to 2065 in the 2010-2011 academic year (dates are taken from the 2012 Spanish Conference of Geology Deans). Van Norden wrote in the early 2000s: 'We do not teach enough geology. We do not graduate enough geology majors, and, worst of all, we are not doing enough to educate the public about the geosciences'. This gap in geoscience knowledge is especially serious among secondary teaching staff (Calonge et al. 2012).

Although biology, chemistry, and physics education are undergoing changes, most American high schools offer year-long courses in these three areas, and most science teachers have majored in one of these subjects. The situation is different for earth science, as most teachers have completed only introductory coursework in the geosciences (King 2008; Lewis and Baker 2010). Lacreu (2017) wrote that in Argentina, the limited geological training of pre-university teachers generates a certain degree of insecurity and fear surrounding teaching geology. This is especially significant in Spain, where many teachers have majored in the biology field of knowledge or in out-of-field general science.

To become a teacher of compulsory secondary education, upper secondary education or vocational training in Spain requires a doctorate or any type of degree qualification issued by a higher education institution (Real decreto 1834/2008, 8 November (BOE 2008) and Real Decreto 860/2010, 2 July (BOE 2010), Spanish Government). In accordance with Article 100.2 of Real decreto 2/2006, teachers must also possess a pedagogical and didactic training master's degree (Real decreto 1834/2008, 8th November and Real Decreto 860/2010, 2nd July, Spanish Government). The master's degree in teacher training in compulsory secondary and upper secondary school education, vocational training and languages of the University of Barcelona is a careeroriented course providing initial training based on the acquisition of skills required to teach compulsory and upper secondary education, vocational training and languages in public and private schools. For any trainee master's degree, successful students accomplish the following main objective: understanding of the curricular content of corresponding teaching specializations and familiarity with relevant teaching and learning processes. According to Lydon and King (2009), continuing professional development workshops for science teachers could improve how earth science is taught by providing new approaches that promote geologically significant learning, increasing knowledge and understanding of the pedagogy of earth science teaching, increasing knowledge and understanding of geology and stressing the value of practical approaches to the teaching of this science.

\section{How Should One Teach and Learn a Subject Such as Geology?}

This is an ever-present question in the mind of a teacher who knows that students could find geology and the geosciences unattractive and unknown subjects. The teaching of the geosciences, as a natural science in its own right, requires principles that reflect the unique features and behaviours of the earth.

Therefore, the study of the geosciences requires a set of thinking and investigative skills that are not commonly found in other areas of the science curriculum or within the curriculum in general. King (2008) identified five educational attributes that play a key role in science education and in 'education for life' that are not well developed elsewhere.

Geoscience is ".. an interpretive and historical science" involving a wide range of methodologies, including those required for retrodictive thinking ('prediction' of 
the past), for large-scale thinking and for integrating large and incomplete data sets.

- Geoscience plays a crucial role in the development of holistic systems thinking, involving consideration of major Earth systems, such as the water and carbon cycles, their interactions and their positive and negative feedback loops.

- Geoscience requires high-level spatial ability thinking (three-dimensional thinking).

- In geoscience, the development of time perspectives is crucial, particularly those of geological time.

- Geoscience fieldwork has particular strategies and methodologies that must be acquired.

However, specific teaching practices are scarcely examined in the literature, especially in reference to geology (Pedrinaci 2013). Leaders in science education have actively promoted inquiry science since the 1960 s and continue to do so today. Some examples include deep understanding encouraged by Earth Science Education Unit (ESEU) facilitators presenting practical workshops to teachers of earth science across the UK (King et al. 2009; King 2017). Deep understanding is also encouraged through Earthlearningideas (Earthlearningidea website) published for free download on the Internet (King et al. 2013). Despite these efforts, however, little has changed in how geological science is taught in secondary school, where teachers' lectures and textbooks are still the primary providers of science information for students (McBride et al. 2004). According to King et al. (2013), earth science content in textbooks around the world is often factually incorrect and may be presented in uninteresting ways. In the early 2000s, Kali et al. (2003) suggested that earth science education was characterized by a shift towards a systems approach. This approach integrates sustainability and environmentalism 'somewhat at the expense of the traditional earth materials, earth structure, earth resources and earth history approach to geoscience curricula' (Vallender 2010).

\section{Earth Science Teaching Principles}

Constructivism is a blanket term used to describe a set of ideas related to how people learn. True acquisition of knowledge happens only when we add new information to previously acquired understanding. According to the constructivists, there is no single methodology but rather a diversity of useful methods. Learning is an active process. In contrast to learning before doing, Pea (2002) proposed focusing on learning in doing, a model in which learners increasingly focus on reallife practices through conversations and activities involving expert practitioners, educators and peers. In fact, as a major benefit of the use of active methodologies, they help students develop their own capacity to research and assume responsibility for their own learning process, in turn solving problems with their own resources (Regueras et al. 2009). When active learning is compared to traditional teaching methods, students demonstrate better comprehension, retain information longer and enjoy their classes much more (Freeman et al. 2014; LoPresto and Slater 2016). Meirieu (1992) proposed organizing learning through problemsolving situations based on the premise that people only integrate new elements if they serve as a solution for a problem situation. The first step of the learning process involves identifying a problem, analyzing it and developing hypotheses for its resolution. Next, students must assess their own ability to solve it, and they should be able to discuss the problem and summarize what they have learned (ChanLin and Chan 2007).

Constructivism also suggests that a good relationship between teachers and students, as well as among students, is required. Teachers act as facilitators and orchestrators who stimulate interaction, guiding students to make joint decisions (Ruiz-Primo 2011). Several authors have researched the use of questions in class as a teaching and learning strategy (Almeida et al. 2008; Albergaria-Almeida 2010a; Chin and Osborne 2008). According to Cotton (1988), oral review questions posed during classroom recitations are more effective than written questions in fostering the acquisition of knowledge.

The tendency is for teachers to ask from 300 to 400 questions per day, accounting for $50 \%$ of class time (Levin and Long 1981). In contrast, students ask, on average, only one question per week (Graesser and Person 1994). Even if teachers ask a large number of questions per class, the questions posed are consistently of the same kind, mainly recall and management questions. They are typically low-cognitivelevel questions that only require memorization. Therefore, teachers spend a large percentage of their communication time asking questions; however, wait time is essential to student thinking. According to Smart and Marshall (2013), it is necessary to train teachers to increase the amount of time allotted to student reflection after asking a question and before a student responds. The teacher can then adjust his or her questioning based on student responses to engage students in the higher-order process of critical thinking and reasoning. Questions are an essential component of active learning in science and scientific inquiry; however, students' questions are usually infrequent (Smart and Marshall 2013).

\section{Research Objective}

A secondary science teacher is in a privileged position to witness and, to a lesser extent, be part of the most important changes in students' thinking and lives. Therefore, science teachers could contribute to increasing the presence and status of geoscience in secondary schools. In this context, this research has three major purposes: (1) to determine the incidence of geology as a topic explored in trainee teachers' 
master's theses; (2) to assess social-scientific issues as a didactic tool in developed geoscience projects; and (3) to provide a thoughtful analysis of techniques, strategies and activities proposed by future teachers in their master's theses to improve secondary students' skills, knowledge and understanding in the geosciences.

\section{Data Collection}

The participants of the study were 177 trainee teachers who were taking a course in teacher training in compulsory secondary and upper secondary school education, vocational training and languages at the University of Barcelona (Spain) in two periods: 2010-2014 and 2016-2017. We reviewed 177 theses of the biology and geology specialization, of which 76 theses dealt with geoscience projects.

\section{Results and Discussion}

\section{Topics Chosen for Master's Theses}

In general, didactic units chosen by the trainee teachers can be grouped into three large groups: $59 \%$ in the field of biological sciences, $20 \%$ in geology and $16 \%$ in environmental sciences (Fig. 1). Although $70 \%$ of trainee teachers study geology as part of their master's degree coursework, they prefer to develop a unit of biology in their master's theses.

Ecosystems, organism kingdoms and biological systems are the most commonly chosen educational units (Fig. 2). These three areas of knowledge belong to the biology field. Plate tectonics $(6 \%)$ and the hydrosphere $(5 \%)$ are concurrent topics in the geoscience field, while pollution and the study of environmental impacts $(9 \%)$ are the themes most chosen by master's degree students in the area of environmental sciences. These themes reflect the current interests of trainee teachers, who feel more confident developing topics that they already know about from their degree studies (biology, biotechnology, biomedical sciences, biochemistry or pharmacy and food sciences). Of trainee teachers in biology, biotechnology, biomedical sciences, biochemistry and pharmacy and food sciences, $43.4 \%$ developed a proposal in the geosciences area, and only $11.8 \%$ developed a proposal in geology. Therefore, the results obtained reflect the good but insufficient influence of geoscience knowledge developed during master's degree studies.

The trainee teachers preferred to develop their didactic unit for compulsory secondary school students of between 12 and 16 years of age (Fig. 3). The most frequently chosen compulsory secondary course was the 3 rd year course for students of 14-15 years of age. It is especially significant that in 3rd year studies, no teaching in geology is provided, and only the issue of environmental impact is explored (DECRET 187/2015, 25 August (DOGC [Official Gazette of the Generalitat de Cataluña] 2015)) (Fig. 4). The trainee teachers also chose to deploy a didactic unit for upper secondary education (baccalaureate) for students aged 16 to 18 (28\%). In this case, the possibility of teaching a higher level of knowledge is a great incentive.

Only four geological topics are studied in compulsory secondary education (DECRET 187/2015, 25 August (DOGC [Official Gazette of the Generalitat de Cataluña] 2015)) and are taught in the 1st (12-13 years of age) and 4th years (1516 years of age). During the 1st year, geological themes explored include the geosphere and geological processes. In the last year of compulsory secondary education, students study tectonic plates and palaeontology. Geological topics are the
Fig. 1 Knowledge area chosen by trainee teachers in Biology and Geology specialization to develop a master's thesis

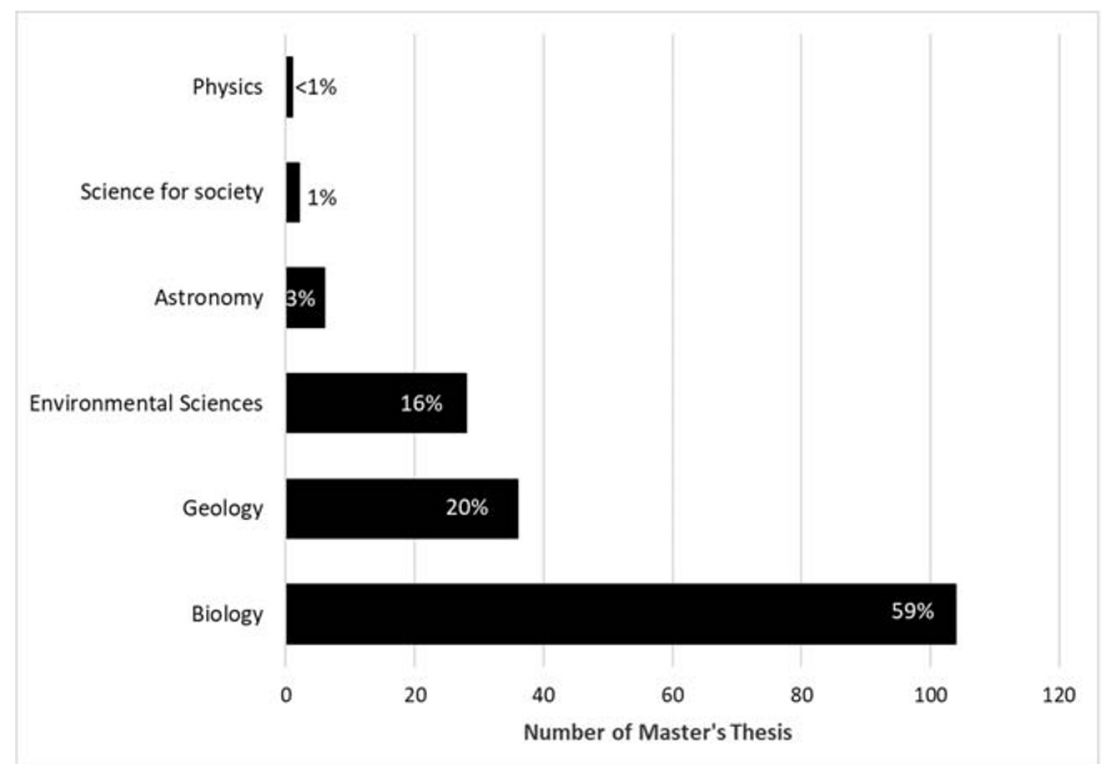




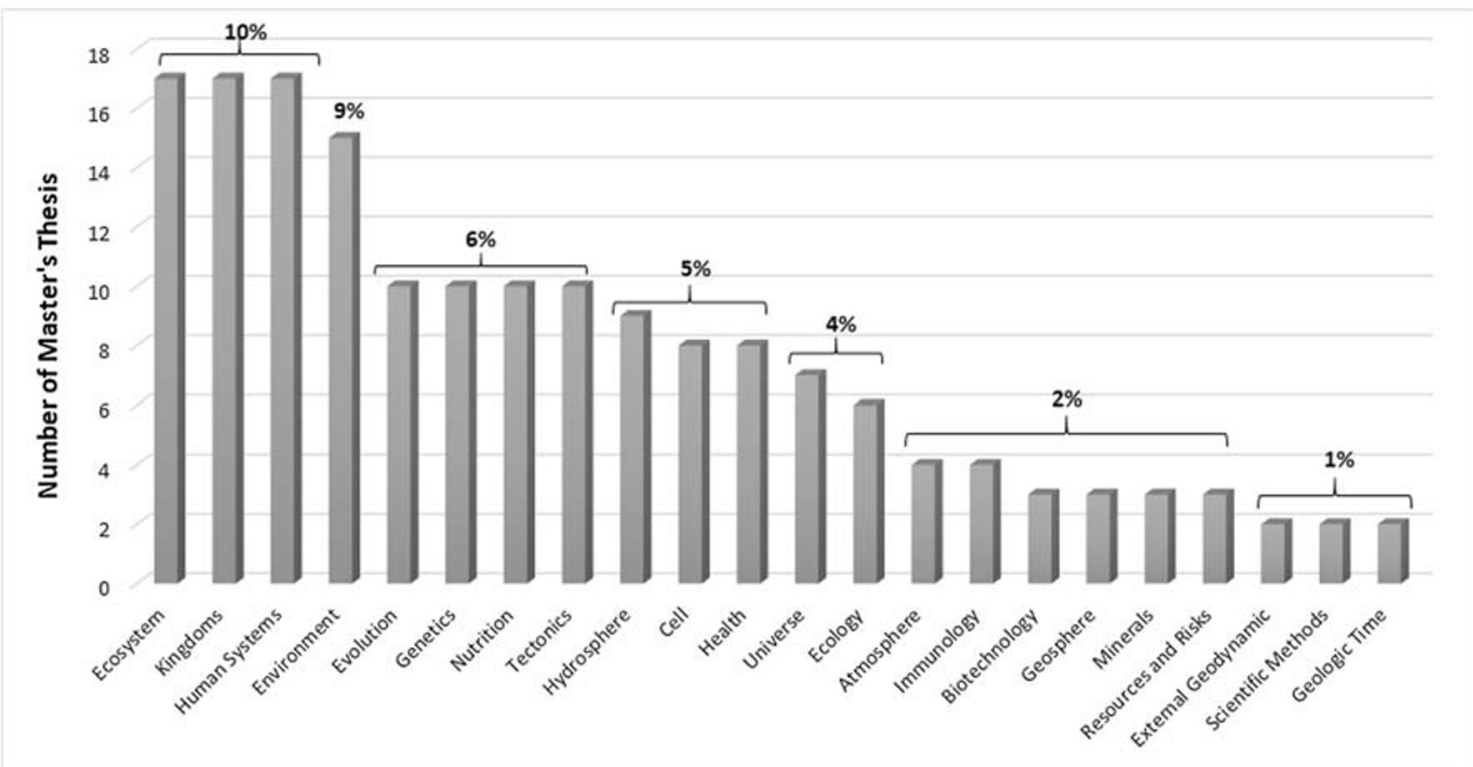

Fig. 2 Ratio, as a percentage, of the teaching didactic units most commonly chosen by trainee teachers

least developed of all compulsory secondary education topics (Pedrinaci 2014), which could be another reason for the nonselection of geology as a topic of master's theses.

\section{Geoscience Projects with Social Impact Issues}

Although discussion of socioscientific issues is uncommon in science classes, the environmental themes developed by the trainee teachers reflected their current interests in proposing to organize learning through problem-solving situations with social impact. Some examples with ethical dimensions used in the didactic proposals are shown in Table 1. Several educators in science have called for the inclusion of controversial socioscientific issues in science curricula due to their potential to create a more real, humane image of scientific activity (Levinson 2006) and to promote scientific literacy, which is an essential tool for responsible citizenship regarding decision-making processes related to socioscientific issues
Fig. 3 Ratio, in percentage, of the course of secondary education in which the teaching units have been developed. Compulsory Secondary Education (ESO) covers 4 years between the ages of 12 and 16 (1ESO, 2ESO, $3 \mathrm{ESO}$ and 4ESO), and baccalaureate covers 2 years between the ages of 16 and 18 (1BAT and 2BAT)

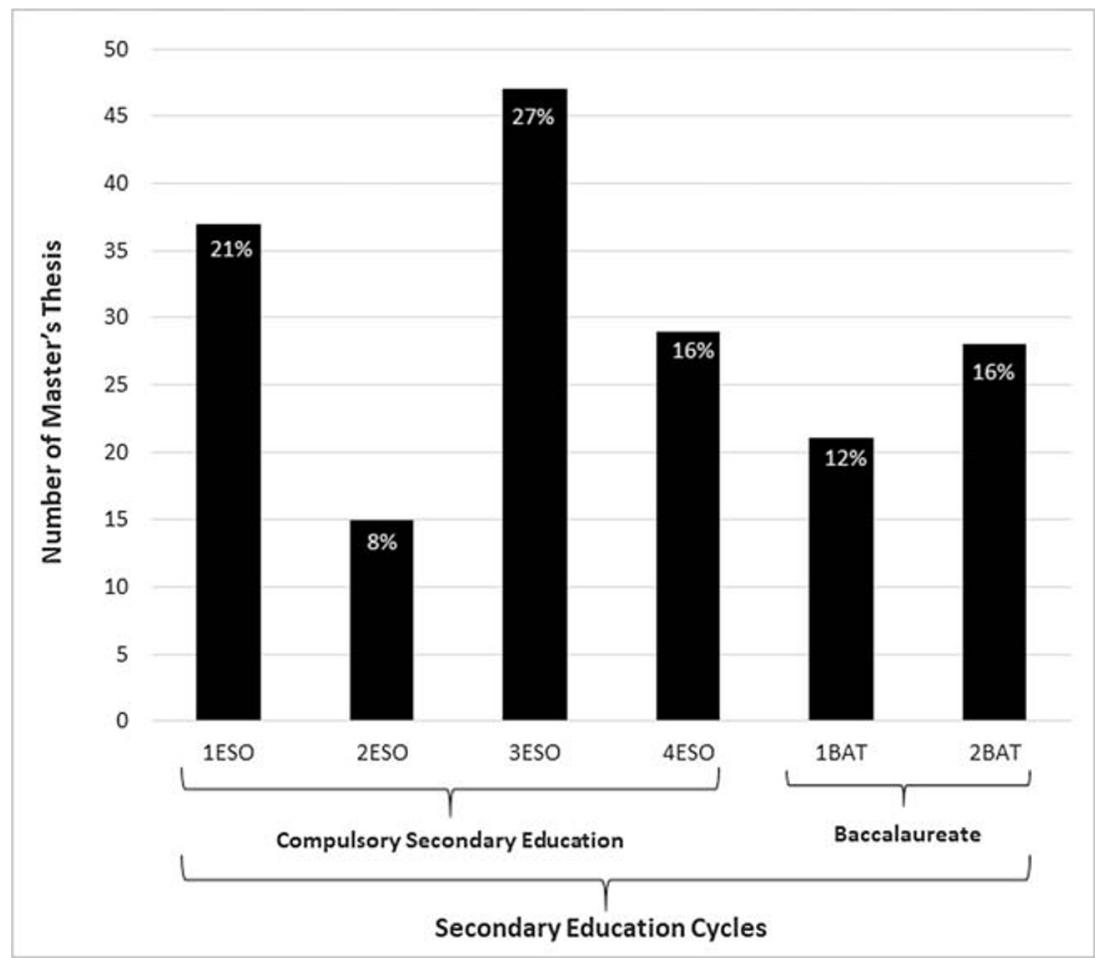


Fig. 4 The 3rd Compulsory Secondary Education (ESO) curricula from DOGC [Official Gazette of the Generalitat de Cataluña] (2015), DECRET 187/ 2015, 25 August. Retrieved from: $\mathrm{http}: / /$ ensenyament.gencat.cat/ web/.content/home/noticies/ actualitat/actualitats2015/decret_ eso.pdf

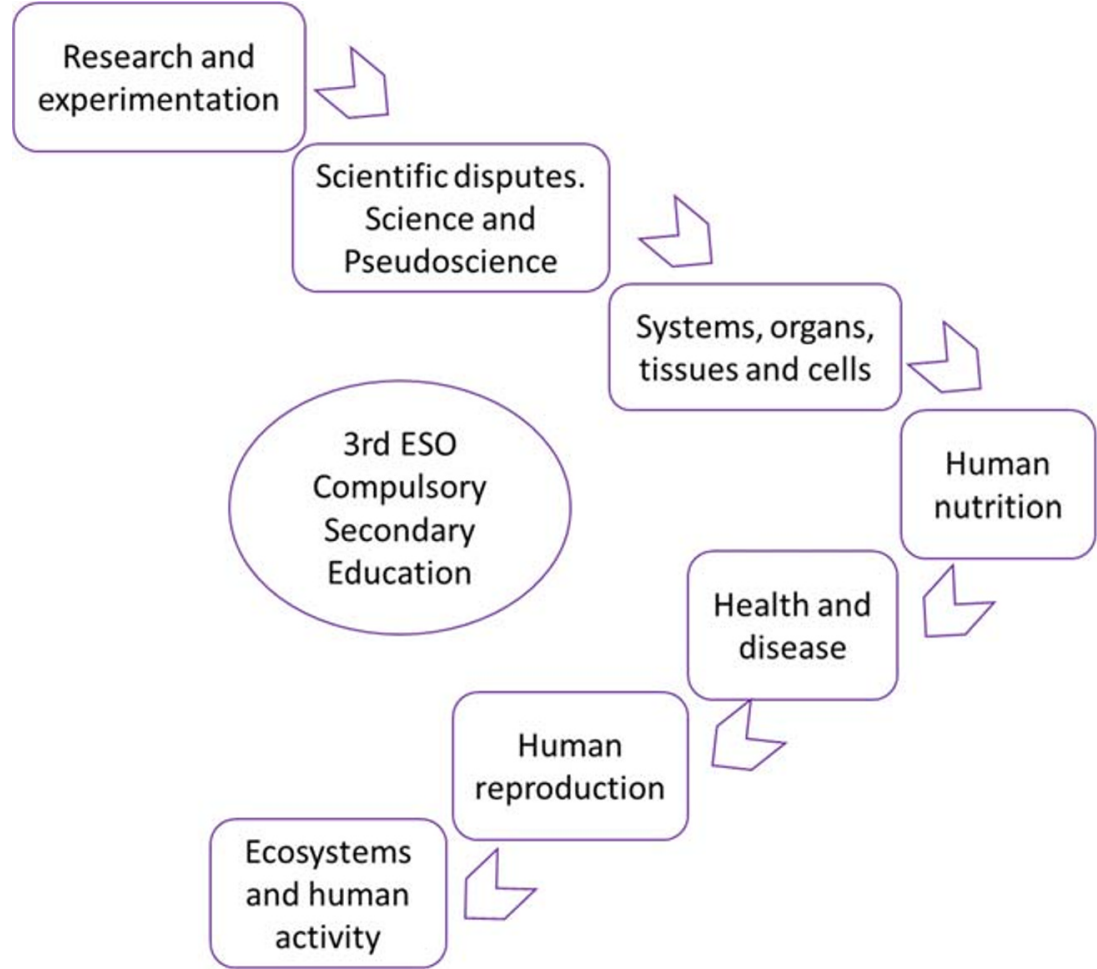

(Reis and Galvão 2009). In the case of the environmental sciences, there are multiple examples of problem situations with social impact; however, most classes develop only scientific aspects. In the case of geology, there are significantly fewer examples (Table 1).

Possible reasons for the lack of discussion of socioscientific issues in science classes include (a) the contentious nature of such issues in that they may be analyzed according to different perspectives, do not lead to simple conclusions and often involve a moral or ethical dimension (Sadler et al. 2004); (b) many teachers' lack of management skills related to leading classroom discussions and the knowledge required to undertake discussions about socioscientific issues, namely, knowledge about the sociological, political, ethical and economic aspects of the issues at hand; (c) fears of protests from students' parents; and, finally, (d) a possible lack of control over discussions (Stradling 1984). However, the inclusion of interactions between science, technology and society could be an essential tool for increasing secondary students' and trainee teachers' interest in the geosciences.

\section{Active Learning Proposals}

Active learning can be promoted through a variety of studentcentred methodologies, namely, through the encouragement of students' problem-solving; through students answering their teachers' questions or formulating questions of their own; or by discussing, explaining, debating or brainstorming during class (Almeida and Neri de Souza 2010). One of the objectives of the master's course is for trainee teachers to try to improve these learning environments through innovation. Even so, the trainee teachers experienced many difficulties imagining innovative proposals due to a lack of practical examples provided during their studies. The exposition of learning material by the teacher was still used by the trainee teachers (Table 2). From our analysis of resources used in the didactic proposals, we observed that the projection of slides (46 cases of 76) in PowerPoint or Prezi format was the most used tool as opposed to classic textbook use ( 15 cases of 76). The traditional educational approach was based on the exposition of learning material by the teacher in addition to addressing students' problems or doubts followed by evaluated examinations and homework. Currently, electronic books are not widely disseminated in secondary schools, which were reflected in their limited use by the trainee teachers in their didactic themes (Table 2).

Conceptual change models of student learning are useful for explicating the role of prior knowledge in students' learning. Research on student cognition has demonstrated that students' prior conceptual knowledge influences all aspects of their processing of information from their levels of information processing and their search for information and comprehension to their thinking and problem-solving (Duit and Treagust 2003). The first step proposed for each teaching unit/curriculum lessons by the trainee teachers as a teaching and learning strategy was brainstorming. This initial activity could involve the use of an oral or a written questionnaire. However, during brainstorming, the teachers typically asked 


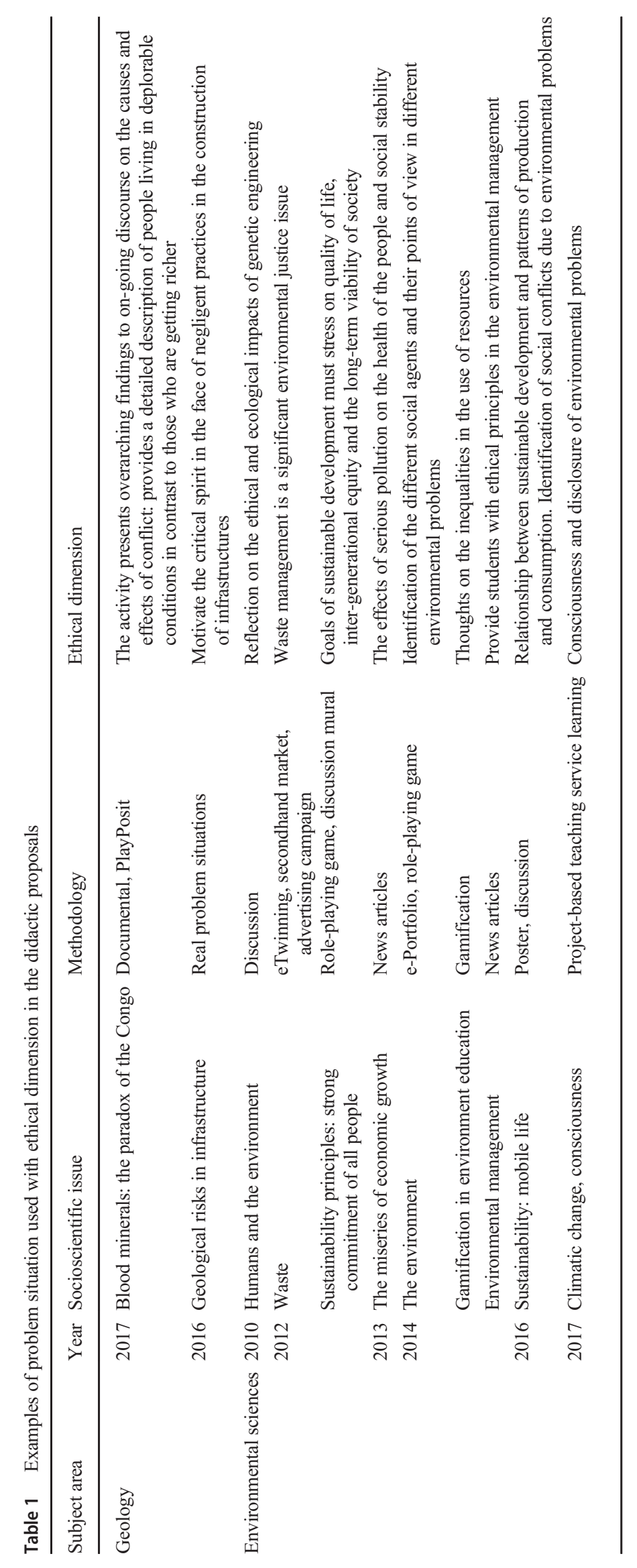


Table 2 Descriptive data of teaching tools used by trainee teachers in their master's theses. In parentheses under each year is the number of geosciences projects

\begin{tabular}{|c|c|c|c|c|c|c|c|c|c|c|c|}
\hline & & & \multicolumn{7}{|l|}{ Year } & \multirow[t]{2}{*}{ Number of cases } & \multirow[t]{2}{*}{$\%$} \\
\hline & & & $\begin{array}{l}2010 \\
(7)\end{array}$ & $\begin{array}{l}2011 \\
(6)\end{array}$ & $\begin{array}{l}2012 \\
(9)\end{array}$ & $\begin{array}{l}2013 \\
(10)\end{array}$ & $\begin{array}{l}2014 \\
(13)\end{array}$ & $\begin{array}{l}2016 \\
(17)\end{array}$ & $\begin{array}{l}2017 \\
(14)\end{array}$ & & \\
\hline \multirow[t]{17}{*}{ Teaching tools } & \multirow[t]{5}{*}{ Teacher-centred teaching tools } & Photocopies & 0 & 2 & 5 & 0 & 1 & 2 & 1 & 11 & 14.5 \\
\hline & & Projection of slides & 5 & 6 & 5 & 6 & 6 & 10 & 8 & 46 & 60.5 \\
\hline & & Classic textbook & 0 & 3 & 3 & 2 & 1 & 6 & 0 & 15 & 19.7 \\
\hline & & Notebook & 1 & 1 & 1 & 1 & 1 & 1 & 1 & 7 & 9.2 \\
\hline & & Expert conferences & 1 & 1 & 5 & 4 & 4 & 5 & 6 & 26 & 5.3 \\
\hline & \multirow[t]{12}{*}{ Student-centred teaching tools } & Web link & 1 & 5 & 8 & 5 & 7 & 10 & 7 & 43 & 56.6 \\
\hline & & Digital blackboard & 0 & 0 & 1 & 1 & 3 & 0 & 1 & 6 & 7.9 \\
\hline & & Tablet & 0 & 0 & 0 & 0 & 0 & 2 & 1 & 3 & 3.9 \\
\hline & & e-Book & 0 & 0 & 0 & 0 & 0 & 0 & 0 & 0 & 0.0 \\
\hline & & Leaflet & 0 & 1 & 0 & 0 & 1 & 0 & 2 & 4 & 5.3 \\
\hline & & Written exercises & 2 & 4 & 7 & 5 & 5 & 14 & 10 & 47 & 61.8 \\
\hline & & Digital portfolio & 0 & 0 & 0 & 1 & 3 & 1 & 1 & 6 & 7.9 \\
\hline & & Classroom diary & 0 & 0 & 2 & 0 & 0 & 2 & 0 & 4 & 5.3 \\
\hline & & Do an article & 0 & 0 & 0 & 0 & 0 & 2 & 2 & 4 & 5.3 \\
\hline & & Oral presentation & 0 & 3 & 7 & 8 & 5 & 10 & 4 & 37 & 48.7 \\
\hline & & Poster presentation & 1 & 1 & 5 & 4 & 4 & 5 & 6 & 26 & 27.6 \\
\hline & & Classroom debate & 1 & 2 & 6 & 3 & 4 & 7 & 6 & 29 & 38.2 \\
\hline
\end{tabular}

low-level questions requiring mainly memorization, and the mean wait time given was, on average, $1 \mathrm{~s}$ or less (AlbergariaAlmeida 2010a). The little time spent answering is one of the handicaps of brainstorming. In the didactic proposals of the trainee teachers, the time interval was between 5 and $15 \mathrm{~min}$ during the first class. However, more time was spent when a previous written questionnaire was administered. In this case, the most common interval of time was 30 min of all activity. Wait time is essential to student thinking.
The reduced wait time can also be attributed to the use of multiple choice quizzes, as these prioritize the speed of answering over the quality of answers given. Multiple choice quizzes appeared in the trainee teachers' theses in 2016, and their use has increased in recent years (Table 3). Therefore, it can be difficult to achieve the steps described by Cotton (1988): reading the question, deciphering the meaning of the question, generating a covert response (i.e. formulating a response in one's mind), generating an overt response and

Table 3 Descriptive data of the use of educational games used by trainee teachers in their master's thesis. In parentheses under each year is the number of geosciences projects

\begin{tabular}{|c|c|c|c|c|c|c|c|c|c|c|}
\hline \multicolumn{9}{|l|}{ Year } & \multirow[t]{2}{*}{ Number of cases } & \multirow[t]{3}{*}{$\%$} \\
\hline & & 2010 & 2011 & 2012 & 2013 & 2014 & 2016 & 2017 & & \\
\hline & & (7) & (6) & (9) & $(10)$ & (13) & (17) & (14) & (76) & \\
\hline \multirow[t]{7}{*}{ Educational games } & Board games & 1 & 0 & 0 & 0 & 2 & 3 & 2 & 8 & 10.5 \\
\hline & Role-playing games & 0 & 0 & 1 & 0 & 0 & 0 & 0 & 1 & 1.3 \\
\hline & Escape room & 0 & 0 & 0 & 0 & 0 & 0 & 1 & 1 & 1.3 \\
\hline & Competition & 0 & 0 & 0 & 0 & 0 & 1 & 0 & 1 & 1.3 \\
\hline & Trivia game & 0 & 0 & 1 & 0 & 0 & 1 & 0 & 1 & 1.3 \\
\hline & Gymkhana & 0 & 0 & 1 & 1 & 0 & 2 & 0 & 4 & 5.3 \\
\hline & Multiple-choice quizzes & 0 & 0 & 0 & 0 & 0 & 3 & 5 & 8 & 10.5 \\
\hline
\end{tabular}


frequently revising the response (based on teacher probing or other feedback).

In recent years, there has been an increasing emphasis on the role played by students' questions in learning science, as questions are an essential component of discursive activity and dialectical thinking (Albergaria-Almeida 2010b). Only six theses of the trainee teachers used relevant thinking strategies and processes (e.g. hypothesizing, predicting and explaining) in their search for an answer. The literature suggests that identifying inquiry questions is the first step of the inquiry process and describes the characteristics of this kind of question. However, Ferrés-Gurt (2017) explained that high school students have difficulty identifying inquiry questions when they make an autonomous inquiry. It has been observed that a conceptual understanding of the phenomenon is a necessary but insufficient element of identifying scientific inquiry questions. The progression from initial information questions such as 'What is...?' or 'Why...?' to adequate inquiry questions such as 'What happens if...?' or 'Might difference be observed if...?' has been monitored, and it has been shown that fluent dialogue between students and teachers enhances this process (Ferrés-Gurt 2017). Project-based learning (PBL) is an innovative approach to learning that is gradually being implemented in schools as a relevant thinking strategy designed to stimulate scientific inquiry questions. Therefore, the number of theses that use relevant thinking strategies should increase in future years. As Chin and Osborne (2008) stated, the formulation of a good question is a creative act and is at the heart of doing science.

\section{Learning Environment Approach}

The context in which learning occurs forms an important paradigm of constructivism. İnelmen (2004 and 2010) explained that 'learning environments' should provide an adequate atmosphere for the development of personal skills needed for life. Three ways of working were observed in the master's theses: problem-based learning, the inclusion of current news articles or television series and educational games (Fig. 5).
Today, television series and videos used in the learning environment are usually obtained from YouTube. In this study, 51 of the trainee teachers used this didactic tool in their theses (Table 4).

Problem-based learning (PBL) has been used to train professionals in diverse fields such as medicine, engineering, law and business. In the 1990s, problem-based learning was conducted in primary and secondary schools (De Witte and Rogge 2016). The approach can be used to enhance students' motivation to learn and to augment their abilities to integrate knowledge from foundation disciplines in pursuit of a solution to practical professional problems. In this case, $31.6 \%$ of the trainee teachers' theses used PBL for their didactic proposals. These examples are especially significant in reference to the analysis of environmental problems (Fig. 6).

Educational games are one of the more successful methods that comply with active learning methods and techniques (Martí-Parreño et al. 2016). Students gain experience, develop tactics, find solutions and make many decisions while playing. Therefore, active learning methodologies can be structured such that students are forced to compete with one another (competitive approach), work individually (individualistic approach) or cooperate with one another (collaborative approach). Few proposals were made by the trainee teachers with only one role-playing game, one escape room and quiz game, and two cases of trivia games (2) mentioned. The most common type of game cited was gymkhana (4 cases) (Table 3). It seems as if the idea of having fun and playing games tends to become less important as students make the transition from primary school to secondary school and then to higher education (Kinchin 2018). However, anecdotally, it seems that learning is much easier when students are having fun and playing games than when they are sitting and concentrating on their learning. A number of studies have examined the value of games and have shown that they can have a positive impact on learning (Viacopoulos and Makri 2017). The number of didactic proposals made in theses that include gamification has increased since 2016, although the number of these proposals is still low. Gamification, as a means to

Table 4 Descriptive data of the use of audiovisual aids used by trainee teachers in their master's thesis. In parentheses under each year is the number of geosciences projects

\begin{tabular}{|c|c|c|c|c|c|c|c|c|c|c|c|}
\hline & & & \multicolumn{7}{|l|}{ Year } & \multirow[t]{2}{*}{ Number of cases } & \multirow[t]{2}{*}{$\%$} \\
\hline & & & $\begin{array}{l}2010 \\
(7)\end{array}$ & $\begin{array}{l}2011 \\
(6)\end{array}$ & $\begin{array}{l}2012 \\
\text { (9) }\end{array}$ & $\begin{array}{l}2013 \\
(10)\end{array}$ & $\begin{array}{l}2014 \\
(13)\end{array}$ & $\begin{array}{l}2016 \\
(17)\end{array}$ & $\begin{array}{l}2017 \\
(14)\end{array}$ & & \\
\hline \multirow[t]{5}{*}{ Audiovisual aids } & \multicolumn{2}{|c|}{ Videos from the Internet } & 2 & 5 & 5 & 9 & 8 & 13 & 9 & 51 & 67.1 \\
\hline & \multirow[t]{2}{*}{ Record a video } & Teacher & 0 & 0 & 0 & 0 & 0 & 0 & 2 & 2 & 2.6 \\
\hline & & Students & 0 & 0 & 1 & 4 & 2 & 4 & 5 & 16 & 21.1 \\
\hline & \multicolumn{2}{|c|}{ Take pictures with a mobile phone } & 0 & 0 & 1 & 0 & 3 & 2 & 2 & 8 & 10.5 \\
\hline & \multicolumn{2}{|l|}{ Videoconference } & 0 & 0 & 0 & 2 & 2 & 0 & 0 & 4 & 5.3 \\
\hline
\end{tabular}


Fig. 5 Column graphs of three types of 'learning environment' observed in the master's theses

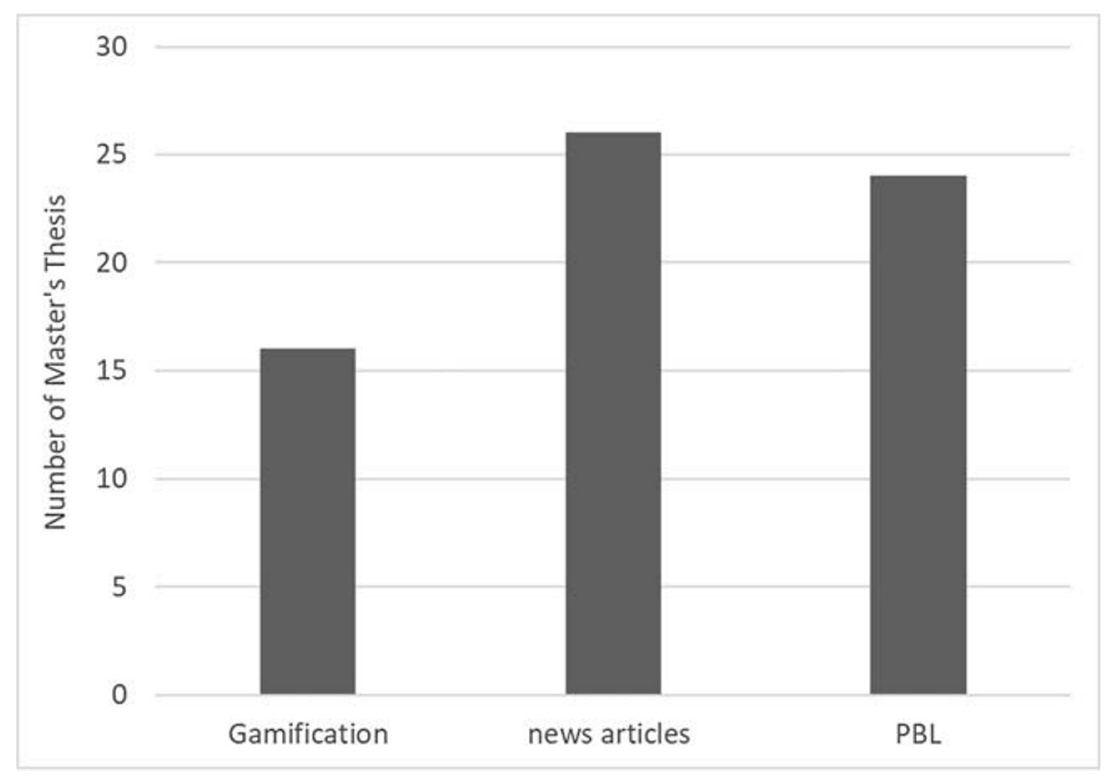

engage members of the millennial generation, is likely to gain considerable ground in didactic proposals over the next few years (Jain and Dutta 2019).

\section{Teaching Innovation: Information and Communication Technology}

Despite large investments made in digital blackboards by the Catalan Autonomic Government (Spain), this specific information and communication technology (ICT) is not used to its full potential and is often used to simply provide a screen on which to project PowerPoint slides (Table 2). One reason for this is the limited use of the full potential of digital blackboards in secondary schools and master's classes of the University of Barcelona. This didactic resource has not been installed in the authors' university classrooms. Therefore, trainee teachers cannot practice all digital blackboard functions during their master's degree studies. This fact could determine its application in the proposed teaching units, representing only 6 cases.

However, the use of digital platforms such as Moodle has increased in recent years (Table 5). Moodle is an environment that facilitates the transmission of information and interactive participation both in real time through videoconferences and in deferred time through chatrooms or forums (Duart and Martínez 2001). However, the use of this digital platform has been limited mainly to a reservoir of studies, presentations or videos as indicated by low levels of WebQuest use (14 cases of 76) and the limited use of forums and chatrooms. In recent years, other platforms have appeared, including Google Classroom ( 2 cases) and Google Drive ( 4 cases). These digital platforms allow for peer interaction and collaboration (Hogan and Fisherkeller 2005), and it is the view of the authors that teachers should support all available spaces for the discussion
Fig. 6 Problem-based learning (PBL) in the teacher trainees' didactic proposals. The number of cases is inside the bars

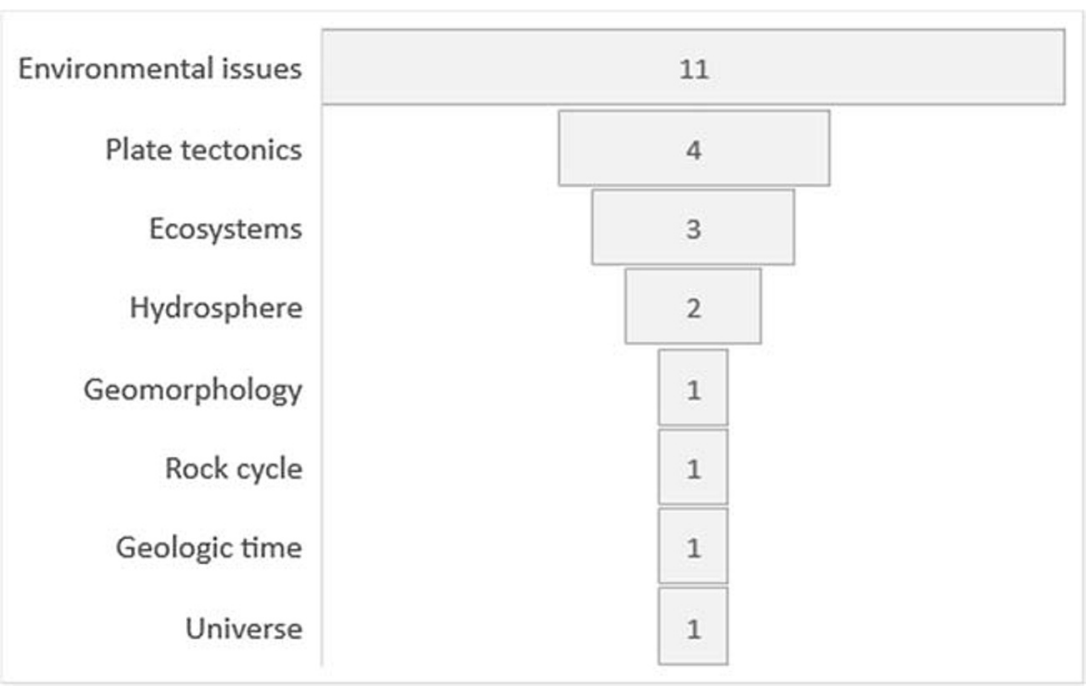


Table 5 Descriptive data of the use of learning management systems and other apps used by trainee teachers in their master's thesis. In parentheses under each year is the number of geosciences projects

\begin{tabular}{|c|c|c|c|c|c|c|c|c|c|c|}
\hline & & \multicolumn{7}{|l|}{ Year } & \multirow{2}{*}{$\begin{array}{l}\begin{array}{l}\text { Number of } \\
\text { cases }\end{array} \\
(76)\end{array}$} & \multirow[t]{2}{*}{$\%$} \\
\hline & & $\begin{array}{l}2010 \\
(7)\end{array}$ & $\begin{array}{l}2011 \\
(6)\end{array}$ & $\begin{array}{l}2012 \\
\text { (9) }\end{array}$ & $\begin{array}{l}2013 \\
(10)\end{array}$ & $\begin{array}{l}2014 \\
(13)\end{array}$ & $\begin{array}{l}2016 \\
(17)\end{array}$ & $\begin{array}{l}2017 \\
(14)\end{array}$ & & \\
\hline \multirow[t]{8}{*}{ Learning management systems } & Moodle & 0 & 0 & 2 & 2 & 4 & 1 & 0 & 9 & 11.8 \\
\hline & Dropbox & 0 & 0 & 2 & 0 & 0 & 1 & 2 & 5 & 6.6 \\
\hline & $\mathrm{B} \operatorname{logs}$ & 0 & 1 & 1 & 2 & 0 & 6 & 1 & 11 & 14.5 \\
\hline & WebQuest & 0 & 0 & 2 & 2 & 1 & 1 & 1 & 7 & 9.2 \\
\hline & Wiki & 0 & 0 & 0 & 1 & 1 & 0 & 0 & 2 & 2.6 \\
\hline & Google Sites & 0 & 0 & 0 & 0 & 0 & 1 & 0 & 1 & 1.3 \\
\hline & Google Classroom & 0 & 1 & 0 & 0 & 0 & 0 & 1 & 2 & 2.6 \\
\hline & Google Drive & 0 & 0 & 0 & 0 & 0 & 3 & 2 & 5 & 6.6 \\
\hline \multirow[t]{2}{*}{ Other apps } & Google Maps & 0 & 1 & 1 & 0 & 3 & 3 & 1 & 9 & 11.8 \\
\hline & Google Scholar & 0 & 0 & 0 & 0 & 0 & 0 & 1 & 1 & 1.3 \\
\hline
\end{tabular}

of peer knowledge such as email, forums, chatrooms and wikis (DeWitt and Siraj 2010). Google Maps, Google Earth and Google Timelapse ( 9 cases) could serve as powerful web pages for geology learning and teaching processes. Despite the amount of technological resources available to teachers today, it is significant that paper-based sources (dossiers, cards, notebooks, etc.) are still commonly used among future teaching professionals, representing 62 cases of the cases surveyed.

In this study, before 2016, only 1 case used a mobile application; however, the number of cases increased between 2016 and 2017 to a total of 6. Mobile phones are a controversial tool in secondary education. In September 2017, the Spanish Minister of Education said in an interview that the Spanish government was exploring the possibility of banning the use of mobile phones in schools following a law imposed in France with the aim of addressing digital addiction among students. The results of Burns and Lohenry (2010) for a university classroom in the USA reveal that mobile phones serve as a source of distraction during class time, and students indicated that they mainly used messaging features. There have also been many studies of the effect of phone ringtones on concentration (Campbell 2006; Röer et al. 2014). However, other educational institutions have rejected the prohibition of the use of mobile phones in the classroom on the premise that their use for pedagogical purposes is positive and because it is impossible to resist technological advances. Tessier (2013) is one example of a study in which students were encouraged to use their mobile phones in an environmental issues course to find data and other information, which they then shared with the class. The students felt that the mobile phones aided their learning, enhanced their enjoyment of the class, improved their success in the course, marginally increased their attendance and were not an important source of distraction. Moreover, mobile phones are currently a necessary tool for many educational games such as Kahoot and Socrative and for QR codes.

Mobile phones also allow students to easily create videos. This is the main reason why the trainee teachers proposed that students make videos to show in the classroom (16 cases). However, there was no editing of the videos except in one case. The only exception was observed in the academic year of 2010-2011, when necessary training was offered to edit videos to take advantage of their potential as a tool (Table 4). Bezjak (2010) identified deficiencies in knowledge of multimedia resources as the main barrier to the implementation of these resources in classrooms.

Virtual reality, an interactive computer-generated experience taking place within a simulated environment, is a learning approach that uses new technologies. These new approaches can increase students' motivation and acquisition of geological knowledge, which are accompanied by an improvement in their grades. Two trainee teachers proposed using virtual reality as a learning approach. The mobile phone facilitates its use in the classroom. The two examples were from 2016 and 2017. The topics chosen were the solar system and the movement of the earth. An example used for solar system teaching is provided at http://toolbox. mobileworldcapital.com/app/solar-system-1/156. This interactive application on the solar system includes 3D graphics and augmented reality. The augmented reality feature allows for an interactive experience of a real-world environment in which objects that reside in the real world are augmented by computer-generated perceptual information. Augmented reality alters the viewer's ongoing perception of a real-world environment, whereas virtual reality completely replaces the user's real-world environment with a simulated environment. 
Table 6 Descriptive data of the use of outdoors activities used by trainee teachers in their master's thesis. In parentheses under each year is the number of geosciences projects

\begin{tabular}{|c|c|c|c|c|c|c|c|c|c|c|}
\hline & & \multicolumn{7}{|l|}{ Year } & \multirow{2}{*}{$\begin{array}{l}\text { Number of cases } \\
(76)\end{array}$} & \multirow[t]{2}{*}{$\%$} \\
\hline & & $\begin{array}{l}2010 \\
\text { (7) }\end{array}$ & $\begin{array}{l}2011 \\
(6)\end{array}$ & $\begin{array}{l}2012 \\
\text { (9) }\end{array}$ & $\begin{array}{l}2013 \\
(10)\end{array}$ & $\begin{array}{l}2014 \\
(13)\end{array}$ & $\begin{array}{l}2016 \\
(17)\end{array}$ & $\begin{array}{l}2017 \\
(14)\end{array}$ & & \\
\hline \multicolumn{2}{|c|}{ Laboratory practices } & 1 & 3 & 5 & 7 & 3 & 7 & 7 & 33 & 43.4 \\
\hline \multicolumn{2}{|l|}{ Field trips } & 2 & 1 & 6 & 4 & 5 & 3 & 3 & 24 & 31.6 \\
\hline \multicolumn{2}{|l|}{ Museum visits } & 0 & 1 & 1 & 3 & 1 & 2 & 1 & 9 & 11.8 \\
\hline \multicolumn{2}{|l|}{ School garden } & 0 & 0 & 0 & 0 & 0 & 0 & 1 & 1 & 1.3 \\
\hline \multirow[t]{2}{*}{ Virtual reality } & Laboratory & 0 & 0 & 0 & 0 & 1 & 0 & 0 & 1 & 1.3 \\
\hline & Field trips & 0 & 0 & 0 & 0 & 0 & 0 & 1 & 1 & 1.3 \\
\hline
\end{tabular}

\section{Field Trips and Laboratory Activities}

In the current teaching structure, the exposition sessions (theoretical or master classes) of field sessions are differentiated. Although fieldwork can be an important component of biology, geography and some history and social science courses, the particular attributes of geoscience fieldwork are very distinct. Most of the final master's theses presented by the trainee teachers cited field trips (32 cases of 76) (Table 6). These results are consistent with what Field et al. (2011) found in the sense that field trip activities are by far the most effective form of learning. Direct contact with the landscape facilitates the understanding of a situation (Hartemink et al. 2014). Therefore, students develop a great range of abilities from particular observational and recording skills to the high-level analysis and synthesis skills necessary for understanding multifaceted field contexts (Field et al. 2011).

Although virtual reality is still an emerging didactic tool, it can offer many opportunities. In 2017, one trainee teacher proposed the creation of a virtual reality project to simulate a field trip. This proposed activity was developed for baccalaureate students to study the geological history of the Iberian Peninsula.

Laboratory practices constitute another example of active learning (Table 6). In this study, 28 of 76 cases used a laboratory practice. These data highlight the fact that the laboratory is also widely used as a form of active learning in the teaching of the geosciences. Today, the virtual laboratory is a computer system designed to simulate the environment of a real laboratory, and through interactive simulations, it enables students to learn laboratory practices. Only one case used the virtual laboratory as a learning approach in a geoscience thesis.

\section{Competence Assessments}

The teaching and learning process must change not only designs or methodological proposals but also the assessment process to emphasize the development of desired competencies. Peer assessment and self-assessment are tools used to evaluate the competencies acquired by students. In the present study, 30 of the studied 76 cases cited peer assessment and self-assessment as tools (Table 7). All these cases applied an evaluation rubric as a follow-up tool in the evaluation of competencies.

Virtual evaluation with the use, for example, of multiplechoice questionnaires (through Moodle or similar platforms) allows for the immediate correction of errors and offers opportunities for students to review their results and improve their knowledge (Hartwell 2010). However, only 6 cases used

Table 7 Descriptive data of the assessment in educational setting used by trainee teachers in their master's thesis. In parentheses under each year is the number of geosciences projects

\begin{tabular}{|c|c|c|c|c|c|c|c|c|c|c|c|}
\hline & & & \multicolumn{7}{|l|}{ Year } & \multirow[t]{2}{*}{ Number of cases } & \multirow[t]{2}{*}{$\%$} \\
\hline & & & $\begin{array}{l}2010 \\
\text { (7) }\end{array}$ & $\begin{array}{l}2011 \\
(6)\end{array}$ & $\begin{array}{l}2012 \\
\text { (9) }\end{array}$ & $\begin{array}{l}2013 \\
(10)\end{array}$ & $\begin{array}{l}2014 \\
(13)\end{array}$ & $\begin{array}{l}2016 \\
(17)\end{array}$ & $\begin{array}{l}2017 \\
(14)\end{array}$ & & \\
\hline \multirow[t]{4}{*}{ Assessment in educational settings } & Didactic strategies & Peer assessment & 0 & 1 & 4 & 2 & 7 & 10 & 6 & 30 & 39.5 \\
\hline & & Self-assessment & 0 & 2 & 4 & 3 & 8 & 9 & 4 & 30 & 39.5 \\
\hline & Instrument: rubric & Continuum & 0 & 0 & 1 & 2 & 9 & 10 & 8 & 30 & 39.5 \\
\hline & & Scale version & 0 & 2 & 0 & 0 & 1 & 2 & 0 & 5 & 6.6 \\
\hline
\end{tabular}


the e-portfolio as a strategy to follow up on the learning and evaluation of acquired competencies. Despite the amount of technological resources available to teachers today, it is significant that paper-based resources (dossier, cards, notebooks, etc.) remain commonly used tools among future teaching professionals. The paper-based resource most used to follow up on learning and evaluation was the dossier, referenced in 47 cases of 76. The personal diary, as a classic but original tool for following up on learning outcomes, was cited in 4 cases.

\section{Conclusions}

The present results clearly indicate that this type of analysis has great potential particularly for evaluating trainee teachers' interest in geoscience and for the analysis of techniques, strategies and activities that improve secondary students' skills, knowledge and understanding in the geosciences. Our research findings provide evidence of a direct link between the university studies of trainee teachers (mainly the biosciences) and topics and courses explored in the educational units of the master's theses. Biological topics grouped into three large groups-ecosystems, organism kingdoms and biological systems - were the most frequently selected by trainee teachers in their master's thesis. Moreover, the most frequently chosen compulsory secondary course was the 3rd year course with students of 14-15 years of age and without geologic curricular content. There is a clear need for critical and open discussion between academia and society on the role of geoscience in education. The challenge, perhaps, would be to combine good structural and conceptual teaching of geosciences with permanent links to attractive interesting topics, i.e. making earth sciences relevant to daily life.

In addition to the need to provide trainee teachers with hands-on experience and practical learning skills with explicit instructions on how to actively participate in and learn less traditional modes, master's degree classes must also serve as a genuine reference model. To date, traditional pedagogical methods such as the projection of slides or the use of classic textbooks have been the most commonly used throughout trainee teachers' education. However, there has been an increasing emphasis on the use of information and communications technologies such as digital platforms or mobile phones and educational games such as role-playing games, escape rooms, quiz games, trivia games and gymkhana to improve active learning in proposed didactic units. The use of PBL is another successful proposed method, as inquiry is an essential component of discursive and thinking activity necessary to improve active learning in proposed didactic units. Environmental themes reflect the current interests of trainee teachers in the proposed organization of learning through problem-solving situations with social impact. The inclusion of current news articles constitutes an example. However, significantly fewer examples are cited in reference to geology. This study demonstrates good implementation in the design and development of assessment processes to emphasize desired competencies. Peer assessment and self-assessment are two successful tools used by trainee teachers in their master's theses to evaluate competencies acquired by students.

With explicit instruction and reference in how to actively participate in and learn less traditional modes, trainee teachers, we believe, will soon come to favour new approaches. These new approaches are relevant due to the current COVID-19 pandemic. School and university closures resulting from the COVID-19 pandemic have forced teachers across the globe to scramble to shift their face-to-face classes (laboratory activities, field trips and evaluations) online. This rapid change has left teachers little time to prepare for virtual teaching and learning. New virtual skills and tools will surely be developed by trainee teachers in future years' theses even after the current health crisis no longer in effect.

\section{References}

Albergaria-Almeida P (2010a) Classroom questioning: teachers' perceptions and practices. Procedia Soc Behav Sci 2(2):305-309

Albergaria-Almeida P (2010b) Questioning patterns, questioning profiles and teaching strategies in secondary education. Int J Learn 17(1): $587-600$

Almeida P, Neri de Souza F (2010) Questioning profiles in secondary science classrooms. Int J Learn Chang 4(3):237-251

Almeida P, Pedrosa de Jesus H, Watts M (2008) Developing a miniproject: students' questions and learning styles. Psychol Educ Rev 32:6-17

Barstow D, Geary E (Eds.) (2002) Blueprint for change: report from the National Conference on the Revolution in Earth and Space Science Education. Cambridge, MA: TERC, Technical Education Research Center, June 21-24, 2001, Snowmass, Colorado

Bezjak J (2010) Contemporary engineer pedagogic's project researchusing multimedia at technology classes in technical and vocational schools. Procedia Soc Behav Sci 2(2):407-411

BOE [Federal Gazette of Spanish Government] (2008). Real D ecreto 1834/2008, 8th November. Retrieved on from: https://boe.gob.es/ buscar/pdf/2008/BOE-A-2008-19174-consolidado.pdf. Accessed $20 \mathrm{Jul} 2020$

BOE [Federal Gazette of Spanish Government] (2010). Real Decreto $860 / 2010$, 2nd July. Retrieved on from: www.boe.es/boe/dias/ 2010/07/17/pdfs/BOE-A-2010-11426.pdf. Accessed 20 Jul 2020

Burns SM, Lohenry K (2010) Cellular phone use in class: implications for teaching and learning a pilot study. Coll Stud J 44(3):805-810

Calonge A, López MD, Meléndez G, Fermeli G (2012) Geoschools, el reto de mejorar la enseñanza de la Geología en la educación secundaria europea. In Actas del XVII Simposio sobre Enseñanza de la Geología, Huelva: Universidad de Huelva publicaciones: 4853. https://www.uhu.es/fexp/segeo2012/arc/comunicaciones/05. pdf. Accessed 14 Nov 2020

Campbell SW (2006) Perceptions of mobile phones in college classrooms: ringing, cheating, and classroom policies. Commun Educ 55(3):280-294 
ChanLin LJ, Chan KC (2007) Integrating inter-disciplinary experts for supporting problem-based learning. Innov Educ Teach Int 44(2): 211-224

Chin C, Osborne J (2008) Students' questions: a potential resource for teaching and learning science. Stud Sci Educ 44(1):1-39

Cotton K (1988) Classroom questioning. School Improv Res Series 5:122

Dawborn-Gundlach ML, Pesina J, Rochette E, Peter Hubber P, Gaff P, Henry D, Gibson M, Kelly L, Redman C (2017) Enhancing preservice teachers' concept of earth science through an immersive, conceptual museum learning program (reconceptualising rocks). Teach Teach Educ 67:214-226

De Witte K, Rogge N (2016) Problem-based learning in secondary education: evaluation by an experiment. Educ Econ 24(1):58-82

DeWitt D, Siraj S (2010) Design and development of a collaborative mlearning module for secondary school science in Malaysia: addressing learners' needs of the use and perceptions of technology. Procedia Soc Behav Sci 2(2):471-475

DOGC [Official Gazette of the Generalitat de Cataluña] (2015). DECRET 187/2015, 25th august. Retrieved on from: http:// ensenyament.gencat.cat/web/.content/home/noticies/actualitat/ actualitats2015/decret eso.pdf. Accessed 20 Jul 2020

Duart JM, Martínez MJ (2001) Evaluación de la calidad docente en entornos virtuales de aprendizaje. Cuadernos IRC, 1-19. Retrieved on from: https://www.uoc.edu/web/esp/art/uoc/0109041/ duartmartin.html. Accessed 14 Nov 2020

Duit R, Treagust DF (2003) Conceptual change: a powerful framework for improving science teaching and learning. Int J Sci Educ 25(6): 671-688

Ferrés-Gurt C (2017) El reto de plantear preguntas científicas investigables. Revista Eureka Sobre Enseñanza y Divulgación de las Ciencias 14(2):410-426

Field DJ, Koppi AJ, Jarrett LE, Abbott LK, Cattle RS, Grant CD, McBratney AB, Menzies NW, Weatherley AJ (2011) Soil science teaching principles. Geoderma 167-168:9-14

Freeman S, Eddy SL, McDonough M, Smith MK, Okoroafor N, Jordt H, Wenderoth MP (2014) Active learning increases student performance in science, engineering, and mathematics. Proc Natl Acad Sci 111(23):8410-8415

Graesser AC, Person NK (1994) Question asking during tutoring. Am Educ Res J 31(1):104-137

Hartemink AE, Balks MR, Chen ZS, Drohan P, Field DJ, Krasilnikov P, Love DJ, Rabenhorst M, van Rees K, Schad P, Schipper LA, Sonneveld M, Walter C (2014) The joy of teaching soil science. Geoderma 217:1-9

Hartwell LM (2010) Impact of software design on on-line text reconstruction. System 38(3):370-378

Hogan K, Fisherkeller J (2005) Dialogue as data: assessing students' scientific reasoning with interactive protocols. In: Mintze JJ, Wandersee JH, Novak JD (eds) Assessing science understanding: a human constructivist view. Elsevier Inc., London, pp 95-127

Jain A, Dutta D (2019) Millennials and gamification: guerilla tactics for making learning fun. South Asian J Human Resour Manag 6(1):29 44

Kali Y, Orion N, Eylon BS (2003) Effect of knowledge integration activities on students' perception of the Earth's crust as a cyclic system. J Res Sci Teach 40(6):545-565

Kinchin IM (2018) Having fun, playing games and learning biology. J Biol Educ 52(2):121-121. https://doi.org/10.1080/00219266.2018. 1451812

King C (2008) Geoscience education: an overview. Stud Sci Educ 44(2): $187-222$

King C (2013) Geoscience education across the globe - results of the IUGS-COGE/IGEO survey. Episodes 36(1):19-30

King C (2017) Fostering deep understanding through the use of geoscience investigations, models and thought experiments - the Earth
Science Education Unit and Earthlearningidea experiences. In: Vasconcelos C (ed) Geoscience education: indoor and outdoor. Springer, Switzerland, pp 3-23 ISBN: 9783319433189

King C, Kennett P, Devon E, Martínez JS (2009) Earthlearningidea: Nuevos recursos para la enseñanza de las ciencias de la tierra en todo el mundo. Ensenanza de las Ciencias de la Tierra 17(1):2-15

King C, Kennett P, Devon E (2013) Earthlearningidea: a worldwide webbased resource of simple but effective teaching activities. J Geosci Educ 61:37-52

Lacreu HL (2017) The social sense of geological literacy. Ann Geophys 60(7):1-6. https://doi.org/10.4401/AG-7558

Levin T, Long R (1981) Effective instruction. Association for Supervision and Curriculum Development, 225 North Washington Street, Alexandria

Levinson R (2006) Towards a theoretical framework for teaching controversial socio-scientific issues. Int J Sci Educ 28(10):1201-1224

Lewis EB (2008) Content is not enough: a history of secondary earth science teacher preparation with recommendations for today. J Geosci Educ 56(5):445-455

Lewis EB, Baker DR (2010) A call for a new geoscience education research agenda. J Res Sci Teach 47(2):121-129

LoPresto MC, Slater TF (2016) A new comparison of active learning strategies to traditional lectures for teaching college astronomy. J Astro Earth Sci Educ 3(1):59-76

Lydon S, King C (2009) Can a single, short CPD workshop cause change in the classroom? Prof Dev Educ 35(1):63-82

Martí-Parreño J, Méndez-Ibáñez E, Alonso-Arroyo A (2016) The use of gamification in education: a bibliometric and text mining analysis. $\mathrm{J}$ Comput Assist Learn 32(6):663-676

McBride JW, Bhatti MI, Hannan MA, Feinberg M (2004) Using an inquiry approach to teach science to secondary school science teachers. Phys Educ 39(5):434-439

Meirieu P (1992) Aprender sí, pero ¿cómo? Octaedro, Barcelona

Pea RD (2002) Learning science through collaborative visualization over the Internet. In Nobel Symposium: Virtual museums and public understanding of science and culture, May 26-29, 2002, Stockholm, Sweden

Pedrinaci E (2012) Alfabetización en Ciencias de la Tierra, una propuesta necesaria. Enseñanza de las Ciencias de la Tierra 20(2):133

Pedrinaci E (2013) Alfabetización en ciencias de la Tierra y competencia científica. Enseñanza de las Ciencias de la Tierra 21(2):208-215

Pedrinaci E (2014) La geología en la educación secundaria: situación actual y perspectivas. Macla 14:32-37

Regueras LM, Verdu E, Munoz MF, Perez MA, de Castro JP, Verdu MJ (2009) Effects of competitive e-learning tools on higher education students: a case study. IEEE Trans Educ 52(2):279-285

Reis P, Galvão C (2009) Teaching controversial socio-scientific issues in biology and geology classes: a case study. Electron J Sci Educ 13(1): $1-24$

Röer JP, Bell R, Buchner A (2014) Please silence your cell phone: your ringtone captures other people's attention. Noise Health 16(68):34 39

Ruiz-Primo MA (2011) Informal formative assessment: the role of instructional dialogues in assessing students' learning. Stud Educ Eval 37(1):15-24

Sadler TD, Chambers FW, Zeidler DL (2004) Student conceptualizations of the nature of science in response to a socioscientific issue. Int J Sci Educ 26(4):387-409

Smart JB, Marshall JC (2013) Interactions between classroom discourse, teacher questioning, and student cognitive engagement in middle school science. J Sci Teach Educ 24:249-267

Stradling R (1984) The teaching of controversial issues: an evaluation. Educ Rev 36(2):121-129

Tessier J (2013) Student impressions of academic cell phone use in the classroom. J Coll Sci Teach 43(1):25-29 
UNESCO (2019a) Geoscience in primary and secondary education, volume 1. Realities and opportunities in Latin America and the Caribbean. International Geoscience and Geoparks programme. https://unesdoc.unesco.org/ark:/48223/pf0000371312. Accessed 17 Sept 2020

UNESCO (2019b) Geoscience in primary and secondary education, Volume 2. Results of Expert's Opinion Survey 2018. International Geoscience and Geoparks programme. https://unesdoc.unesco.org/ ark:/48223/pf0000371311. Accessed 17 Sept 2020
Vallender GD (2010) Geological science education and conceptual change (Doctoral dissertation, Curtin University). Retrieved on from: https://espace.curtin.edu.au/bitstream/handle/20.500.11937/ 1806/151691_Vallender2010.pdf? sequence=2. Accessed 16 Sept 2020

Viacopoulos D, Makri A (2017) The effect of games and simulations on higher education: a systematic literature review. Int J Educ Technol High Educ 14:22 